\title{
Parodiju veidošana kā autora tiesību ierobežojums
}

\author{
Dr. iur. Ingrīda Veikša \\ ORCID: 0000-0002-8253-1926 \\ Biznesa augstskola Turība, Juridiskā fakultāte, \\ Tiesību zinātṇu katedra, Latvija \\ ingrida.veiksa@turiba.lv
}

\section{Kopsavilkums}

Autora veidotu literatūras vai mākslas darbu atsevišḳos gadījumos drīkst izmantot bez autora atḷaujas, pamatojoties uz likumā noteiktajiem autortiesību ierobežojumiem. Šo ierobežojumu mērḳis ir nodibināt līdzsvaru starp autora un sabiedrības tiesībām. Viens no tiesību ierobežošanas veidiem ir parodiju un karikatūru veidošana, kas ir būtiska vārda brīvības sastāvdaḷa. Tajā pašā laikā autoram ir tiesības uz pretdarbību sava darba izkropl̦ošanai, jo starp parodiju un izkropḷošanu ir l̦oti šaura robeža. Tas, kas šḳiet smieklīgs joks vienam cilvēkam, citam var šķist aizskārums un aizvainojums. Ja autors uzskata, ka viņa darbs ir izkropḷots, ka tas aizskar autora godu vai cieņu, tad šāda rīcība veido autora personisko tiesību aizskārumu un uzskatāma par pārkāpumu. Lai maksimāli izvairītos no neatbilstošu parodiju vai karikatūru radǐšanas, Latvijas Republikas Autortiesību likumā būtu ieteicams veikt grozījumus, kas noteiktu kritērijus līdzsvaram starp autora tiesībām uz viṇa darba cien,pilnu izmantošanu un sabiedrības tiesībām uz vārda brīvību un cenzūras nepiel̦aujamību.

Atslēgvārdi: autortiesības, vārda brīvība, parodija.

\section{levads}

Autora veidots literatūras vai mākslas darbs ir kā viṇa bērns, neviens cits to nedrīkst paņemt bez atḷaujas. Tomēr (atšḳirībā no bērna) autordarbu atsevišķos gadījumos drīkst izmantot, neprasot autora piekrišanu. Eiropas Savienībā tos sauc par autortiesību ierobežojumiem, angloamerikāṇu tiesību sistēmas valstīs - par godprātīgu izmantošanu, un šo noteikumu galvenais mērḳis ir nodibināt līdzsvaru starp autora un sabiedrības tiesībām. 
Viens no tiesību ierobežojuma veidiem ir tiesības veidot parodijas un karikatūras, kas ir būtiska vārda brīvības sastāvdaḷa. Tajā pašā laikā autoram ir tiesības uz pretdarbību sava darba izkroplıšanai.

Vārds "parodija" ir cēlies no sengrieḳu vārda parōdia, kas burtiskā tulkojumā nozīmē "apgriezta dziesma". Tas ir humoristisks vai ironiski satīrisks darbs (piemēram, literārs sacerējums, kurā atdarināta kādas parādības ārējā izpausme, literāra stila vai virziena īpatnības, apzināti sagrozot šās parādības būtỉbu). Parodijai ir tikai ārēja, attāla, arī izkroplota līdzība ar attiecīgā objekta (parādības) būtību [18].

No definīcijas redzams, ka starp parodiju un darba izkropl̦ošanu ir l̦oti šaura robeža. Tas, kas vienam cilvēkam šķiet smieklīgi, citam var šḳist aizskārums un aizvainojums. Ja autors uzskata, ka viņa darbs ir izkroplots, ka aizskarts autora gods vai cieņa, tad šāda rīcība veido autora personisko tiesību aizskārumu un uzskatāma par pārkāpumu. Lai maksimāli izvairītos no neatbilstošu parodiju vai karikatūru radīšanas, Latvijas Republikas Autortiesību likumā būtu ieteicams veikt grozījumus, kas noteiktu kritērijus līdzsvaram starp autora tiesībām uz viṇa darba cieṇpilnu izmantošanu un sabiedrības tiesībām uz vārda brīvību un cenzūras nepiel̦aujamību.

Rakstā tiek aplūkoti autortiesību vispārīgie noteikumi, sākot ar Latvijas Republikas Satversmē noteikto autortiesību aizsardzības konstitucionālo pamatu. Šeit tiek analizēts autora personisko tiesību tvērums un mantisko tiesību ierobežojumi parodiju un karikatūru veidošanai. Publikācijā netiek aplūkoti parodiju un karikatūru veidošanas vispārīgie principi, bet gan tikai to veidošana no autortiesību aspekta. Netiks aplūkoti, piemēram, ar pravieša Muhameda karikatūru publicēšanu saistītie jautājumi, jo šajā gadījumā tika aizskartas nevis autora, bet gan religíiskas kopienas jūtas, kas ir ārpus šì pētījuma tvēruma.

\section{Pētijuma metode}

Pētỉjuma jautājums ir, vai iespējams izveidot parodiju vai karikatūru, nodrošinot vārda brīvību un vienlaikus neaizskarot autoru personiskās tiesības? Lai rastu atbildi uz šo jautājumu, tika pētīti gan starptautiskie, gan nacionālie tiesību akti, pētījumi, starptautisko konferenču materiāli, kā arī internetā pieejamā informācija par parodiju un karikatūru veidošanu. Pētījumā tika izmantota analītiskā metode, lai analizētu atsevišḳu pētnieku darbus par līdzsvaru starp autoru personīgajām un mantiskajām tiesībām un vārda brīvību. Salīdzinošā metode izmantota, lai salīdzinātu atsevišḳu valstu normatīvo regulējumu šajā jomā. Izmantota arī tiesību normu interpretācijas metode, lai novērtētu esošo tiesību normu atbilstību vai neatbilstîbu un ierosinātu nepieciešamos grozījumus normatìvajos aktos.

\section{Autora personiskās tiesības}

Autortiesības ir divējādas - personiskās jeb morālās un mantiskās jeb ekonomiskās tiesības. Personiskās tiesības netiek uzskatītas par īpašumu, bet gan par autora personības aspektu. Personīgo tiesību pamatā ir ideja aizsargāt autoru ārpus viṇa ekonomiskajām 
interesēm, proti, vina intelektuālajās, mākslinieciskajās un līdzīgās nemantiskās interesēs. Vairumā precedenta tiesību valstu dažādās variācijās paredzētas vismaz trīs personīgās tiesības: izziṇošanas tiesība, autorības vai paternitātes tiesība un darba integritātes tiesība $[19,680]$. Tàs ir neatvasināmas, tās var izmantot vienīgi pats autors sava mūža laikā, bet pēc viṇa nāves šīs tiesības var izmantot viṇa mantinieki autora vārdā.

Prasība iekḷaut nacionālajos likumos autora personīgo tiesību aizsardzību izriet no Bernes konvencijas, kurā cita starpā ir noteiktas arī autora tiesības iebilst pret jebkādu sava darba izkroploššanu un autora tiesību aizskaršanu, kas var kaitēt autora godam vai reputācijai [2].

Latvijā autoriem ir noteiktas tiesības uz pretdarbību jebkurai sava darba izkroplošanai, sagrozīšanai vai citādai pārveidošanai, kā arī tādai autora tiesību aizskaršanai, kas var kaitēt autora godam vai cien̦ai [1]. Dažkārt autors var uzskatît, ka viņa darba izmantošana veidā, kādā tas tiek darīts, aizskar viṇa godu un cieṇu. Piemēram, autors, būdams pārliecināts pacifists, uzraksta romānu par mieru, bet filmas scenārists vai režisors to ir pārvērtis tā, ka filma slavē karu. Autoram šādā gadījumā būs pilnīgs pamats uzskatīt, ka viña darbs ir izkroplots un ir aizskarts viña gods un cieña, un darba izmantošana šādā veidā ir apturama. Ja tiks pierādīts (parasti ar tiesas palīdzību), ka autora gods vai cieņa tiešām ir aizskarti, darba izmantošana tiks apturēta, un autoram nebūs jāatlīdzina zaudējumi.

Tikpat lielā mērā kā Latvijā personīgās tiesības autoriem ir piešḳirtas arī Lietuvā: darba autoram ir autorības tiesības un tiesības iebilst pret jebkādu darba sagrozišanu vai pārveidošanu, kas varētu kaitēt autora godam vai reputācijai [8].

Līdzīgi noteikumi ir iekḷauti visu valstu, kuras ir pievienojušās Bernes konvencijai, nacionālajos likumos. Angloamerikānu (precedenta tiesību, angḷu val. common law) valstīs personisko tiesību doktrīna tiek atzīta iespējami šaurākajā apmērā. Tās teorētiskais pamats nav stingri noteikts, tā vietā tiek meklēts atbalsts no doktrīnām par neslavas celšanu, negodīgu konkurenci un no privātuma tiesībām [16, 109]. Piemēram, Kanādas autoriem ir tiesības uz darba integritāti (14.1. pants), un šo personīgo tiesību pārkāpums ir gadījumā, ja darbs tiek sagrozìts, izkropḷtots vai citādi pārveidots tā, ka tas aizskar autora godu vai cien̦u (28.2. pants) [3].

Lai arī dažādu valstu likumos pantu redakcijas atšḳiras, tomēr var droši apgalvot, ka minimālie (Bernes konvencijā ietvertie) autora personisko tiesību aizsardzības standarti tiek ievēroti visās civilizētajās valstīs, jo Bernes konvencijai saskaṇā ar Vispasaules intelektuālā īpašuma organizācijas (WIPO) sniegto informāciju šobrīd ir pievienojušās 179 dalïbvalstis [25].

Jāpiekrīt viedoklim, ka personīgās tiesības šodien vairs nav pielietojamas tik vienkārši un plaši, kā tās tika definētas Bernes konvencijas pieṇemšanas laikā. Izglītotajām un izcilajām personībām, kas šos noteikumus pieṇēma 1928. gadā un pēc 20 gadiem ar lielu rūpību pārskatīja Briselē, acīmredzot bija prātā grāmatas, lugas, simfonijas, koncerti un tamlīdzīgi tiesību objekti [12, 152]. Mūsdienu tehnolog̣iju attīstības līmenī personiskās tiesības reizēm var aizkavēt daudzu līdzautoru kopīgi radītu darbu (piemēram, 
Ingrīda Veikša. Parodiju veidošana kā autora tiesību ierobežojums

datorprogrammu, arhitektūras projektu, filmu u. tml.) izmantošanu, tādējādi pat kaitējot autora interesēm.

\section{Autora mantiskās tiesības un to ierobežojumi}

Lai autors varētu dzīvot no sava darba aug̣̣iem, viṇam jāsaṇem atlīdzība par savu veikumu. Tādēl Latvijas Republikas Autortiesību likumā saskaṇā ar Bernes konvencijas un Vispasaules intelektuālā īpašuma organizācijas (WIPO) Lìguma par autortiesībām prasībām autoram tiek noteiktas tiesības savu darbu kopēt, izplatìt, publiskot, publicēt, raidìt, retranslēt, ievietot internetā, nodot lietošanā uz laiku, tulkot, pārveidot u. tml. Viņš to var darīt pats vai arī aț̣aut to darīt citām personām un saṇemt par to atlīdzìbu (15. panta pirmā daḷa). Jebkurš darba pārveidojums jāsaskaņo ar autoru, pretējā gadījumā var tikt uzskatīts, ka ir aizskartas ne vien autora mantiskās, bet arī personiskās tiesības. Lai iegūtu darba izmantošanas tiesības, darba izmantotājiem ir jāsaṇem autortiesību subjekta aț̣auja un ir aizliegts izmantot darbus bez aț̣aujas saṇemšanas (40. pants).

Autortiesības ir monopoltiesības uz noteiktu laiku, ko nacionālie likumi piešḳir darba veidotājam. Bet autortiesību īpašniekam piešḳirtās tiesības nav absolūtas, jo tās ietver arī nosacījumus par darba godīgu izmantošanu zināšanu un sabiedrības attīstības veicināšanai, kas nav nedz autortiesību pārkāpums, nedz plagiaāts [21, 87]. Sabiedrībai ir tiesības uz vārda brīvību, kas ietver arī tiesības brīvi iegūt, paturēt un izplatìt informāciju, tai skaitā arī ar humoru vai satīru piesātinātas darbu parodijas un karikatūras. Tiesību ierobežojumi ir tikpat veci kā visa autortiesību sistēma kopumā. Tie parādījās jau 19. gadsimta Eiropas autortiesību likumos. Bernes 1886. gada konvencija, vecākā konvencija pasaulē, jau definē šos jēdzienus. Tradicionālie Bernes konvencijas ierobežojumi eksistē dažādos formātos, attiecina tos uz politiskām runām, citātiem, izmantošanu izglìtības mērḳiem, mediju darbu, atl̦aujot aizṇemties vienam no otra u. tml. [14, 359].

Eiropas Savienībā ir noteikta stingra kārtība, un autortiesību ierobežojumi ir skaidri nosaukti un uzskaitīti, paplašināta tulkošana nav piel̦aujama. Informācijas sabiedrības direktīvā ir sniegts pilnīgs ierobežojumu saraksts, ko dalībvalstis var ieviest savos tiesību aktos, arī tiesība noteikt ierobežojumus autordarbu izmantošanai karikatūrās, parodijās vai stilizācijās [5, 5. panta trešās daḷas K punkts]. Tas pats noteikts arī Vienotā digitālā tirgus direktīvā: lietotāji, kad tie augšupielādē saturu, ko generējuši lietotāji tiešsaistes satura kopīgošanas pakalpojumos, var atsaukties uz jebkuru no spēkā esošajiem ierobežojumiem, to skaitā uz izmantošanu karikatūrās, parodijās vai stilizācijās [4, 17. panta 7. punkts].

Saskaṇā ar Latvijas Republikas Autortiesību likuma 19. pantu ir noteikts, ka atsevišķos gadījumos autora darbu var izmantot bez autora piekrišanas un atlīdzības, un viens no šiem gadījumiem ir darba parodēšana vai kariḳēšana (9. punkts). Taču likumā arī noteikts, ka šāda izmantošana nedrīkst būt pretrunā ar autora darba normālas izmantošanas noteikumiem un nepamatoti ierobežot autora likumīgās intereses vai radīt viņam zaudējumus. Šaubu gadījumā jāpien,em, ka autora tiesības nedrīkst tikt ierobežotas (18. pants). 
ASV un citās precedenta tiesību valstīs pastāv tā sauktais godīgas izmantošanas (angḷu val.fair dealing) princips. Piemēram, godīgas izmantošanas ierobežojums saskaṇā ar Kanādas Autortiesību likumu aț̣auj autordarba godīgu izmantošanu parodijas vai satīras vajadzībām [3, 29. pants]. Tas pats noteikts arī Apvienotās Karalistes likumā: godīga rīcība ar darbu karikatūras, parodijas vai stilizācijas veidošanai nepārkāpj darba autortiesības [9, 30. A pants]. Šo ierobežojumu Apvienotās Karalistes tiesas jau kopš 1911. gada interpretē atbilstoši "godīgas izmantošanas" jēdzienam, kura saturs nav definēts likumā, bet gan pakāpeniski attīstìts tiesu praksē [17, 28]. Godīga izmantošana tiek vērtēta arī no tā, cik liela aizsargātā darba dạ̣a tiek izmantota iepriekšminētajiem mērkiem. Piemēram, ir atḷauts izmantot vienas minūtes klipu ar Džona Veina (John Wayne) tēlu dokumentālā filmā par mežonīgajiem Rietumiem. Taču Džona Veina tēla izmantošana Super Bowl Sunday alus reklāmā noteikti nav aţ̣auta [15, 186].

\section{Sabiedrības tiesības uz vārda brīvību}

Katrai autortiesību sistēmai ir jāsabalansē divas sabiedrību interesējošas tiesības: tiesības, kas pienākas autortiesību īpašniekiem, un organizētās sabiedrības saprātīga pieprasījuma tiesības [22, 5]. Visos autortiesību strīdos šie divi pamatprincipi gandrīz vienmēr nemainīgi saduras: no vienas puses, ir nepieciešamība aizsargāt darba radītāja finansiālās intereses, no otras puses, - nepieciešamība nodrošināt katram indivīdam tiesības piekḷūt cilvēces uzkrātajām mākslas un zināšanu bagātībām [23, 38].

Abas šĩs autortiesību prasības ir labi definētas Cilvēktiesību deklarācijas 27. pantā. Organizētās sabiedrības tiesības ietvertas pirmajā dạ̦ā ("katram cilvēkam ir tiesības brīvi piedalīties sabiedrības kultūras dzìvē, baudìt mākslu, piedalīties zinātnes progresā un izmantot tā labumus"), savukārt autortiesību īpašnieku tiesības - otrajā dạ̣ā ("katram cilvēkam ir tiesības uz morālo un materiālo interešu aizsardzību, kas saistītas ar zinātniskajiem, literārajiem vai mākslas darbiem, kuru autors viṇš ir") [10].

Latvijas Republikas Satversmes 113. pantā noteikts, ka valsts atzīst jaunrades brīvību, kā arī aizsargā autortiesības un patenttiesības - tātad saikne starp valsti un autortiesībām ir ielikta jau mūsu pamatlikumā. Savukārt 105. pantā ikvienam ir garantētas tiesības uz ìpašumu. İpašums var būt gan taustāms, gan netaustāms, un viens no netaustāmā īpašuma veidiem ir intelektuālais īpašums. Tajā pašā laikā Latvijas Republikas Satversmē ir arī 100. pants, kurā noteikts, ka ikvienam sabiedrības loceklim ir tiesības brīvi iegūt, paturēt un izplatīt informāciju. Kā zināms, Satversmes 116. pantā noteikts, ka informācijas ieguves un izplatīšanas tiesības var ierobežot likumā paredzētajos gadījumos, lai aizsargātu citu cilvēku tiesības, demokrātisko valsts iekārtu, sabiedrības drošību, labklājību un tikumību [6].

Nepieciešams ir atrast līdzsvaru starp šīm Satversmē minētajām cilvēktiesībām, lai nodrošinātu gan autoru tiesības uz viṇu îpašuma aizsardzību, gan sabiedrības tiesības uz informācijas ieguvi un izplatǐšanu. 


\section{Parodijas un karikatūras godprātīga veidošana}

Lai gan vairumam ierobežojumu Latvijas Republikas Autortiesību likumā ir pievienoti skaidrojoši komentāri, tomēr tajā nav skaidrojumu par darbu izmantošanu parodijās vai karikatūrās - ne par to veidiem, ne apjomu, ne termiṇiem. Lìdz ar to pārkāpumu gadījumā Latvijas tiesas, visdrīzāk, vadīsies pēc Eiropas Savienības Tiesas (EST) secinājumiem lìdzīgās lietās. Piemēram, EST spriedumā lietā Nr. C-201/13 teikts, ka termins "parodija" jāinterpretē, n,emot vērā tā parasto nozīmi ikdienas valodā, vienlaikus n,emot vērā arī kontekstu, kurā tas sastopams, un to noteikumu mērḳus, kuros tā ietilpst [11].

Parodijas būtiskākā iezīme, pirmkārt, ir radīt kādu darbu, kas vienlaikus gan atbilst jau esošajam, gan ievērojami atškiriras no tā, un, otrkārt, pievienot darbam humora vai izsmiekla izpausmi. Jēdziens "parodija" nav pakḷauts nosacījumam, ka parodijai ir jābūt oriǵinālai, uz to neattiecas arī prasība minēt parodētā darba avotu. EST uzsver, ka ir jāievēro taisnīgs līdzsvars starp parodētā darba autora interesēm un tiesībām, no vienas puses, un darba parodētāja vārda brīvību, no otras puses. Līdz ar to saprotams, ka darbs tiks atzìts par parodètu nevis izkroplıtu, ja tam tiks pievienota humora vai izsmiekla izpausme un ja tiks nodrošināts līdzsvars starp autora un izmantotāja tiesībām un interesēm. Pretējā gadījumā to var uztvert kā darba izkropḷošanu, kas ir personīgo tiesību pārkāpums, vai arī par nelikumīgu darba izmantošanu, kas ir mantisko tiesību pārkāpums.

Lielbritānijas Intelektuālā īpašuma birojs 2013. gadā veica apjomīgu pētījumu par parodiju un karikatūru veidošanas regulējumu septiṇās valstīs: Lielbritānijā, Kanādā, Francijā, Austrālijā, Vācijā, ASV un Nīderlandē. Pètỉjuma autori secināja, ka parodijas nerada ekonomiskus zaudējumus autoram un arī reputācijas kaitējums ir ḷoti ierobežots. Parodiju piel̦aušana novatoriskiem tiesību subjektiem ir ievērojams ieguvums, kas var pārvērsties par ekonomisku izaugsmi. Parodiju (un ar tām saistīto kultūras aktivitāšu) aț̣aušana brīvā sabiedrībā galvenokārt balstās uz neekonomiskiem apsvērumiem - vārda un izteiksmes brīvību [20].

Šeit var atcerēties senu strīdu starp Jāni Rušenieku (Latvijas Televīzijas raidījuma "Mūzika un video" veidotāju) un Viesturu Dūli (Latvijas Neatkarīgās televīzijas raidījuma "Ak, kungs" veidotāju), kas aizsākās 2002. gadā. Strīds beidzās ar Augstākās tiesas spriedumu par labu Jānim Rušeniekam, lai gan materiālā prasība dậeji tika noraidìta. Raidījumā "Ak, kungs" tika parodēta Rušenieka intervija ar Juri Kulakovu. Parodētais Kulakovs lēnīgi atbildēja uz jautājumiem, kamēr Dūles tēlotais Rušenieks, garlaicīgi izvaicājot Kulakovu, paguva noskūt bārdu, iztīrìt zobus un aiziet uz tualeti. Dažādi bija radošās vides pārstāvju viedokḷi par šo parodiju un par strīda iznākumu. Daži uzskatīja, ka parodijas žanrs ar likumu nav aizsargāts, jo iesūdzēt tiesā var arī avīzi par karikatūras publicēšanu tajā [13]. Citi norādīja, ka raidījuma "Ak, kungs" veidotāji ir balansējuši uz parodijas un rupjïbas robežas, taču sūdzēt viṇus tiesā ir tas pats, kas "čukčam vai igaunim mēgināàt piedzìt naudu no anekdošu stāstītājiem" [24]. Jāpiebilst, ka strīda izskatīšanas laikā Latvijas Republikas Autortiesību likumā nebija ietverts šāds autora tiesību ierobežojums, to iekḷāva tikai 2004. gadā, lai nodibinātu pamatu tiesībām veidot parodijas un karikatūras. 


\section{Secinājumi}

Veidojot parodijas, vienmēr jāatceras, ka starp parodiju un izkropḷošanu ir ḷoti šaura robeža. Tas, kas šḳiet smieklīgs joks vienam cilvēkam, citam var šḳist morālo tiesību pārkāpums, liels aizvainojums un darba izkroplošana. Lai izvairītos no neatbilstošu parodiju vai karikatūru radīšanas, Latvijas Republikas Autortiesību likumā būtu ieteicams skaidrāk noteikt, ka, izmantojot šo ierobežojumu, ir jānodrošina līdzsvars starp autortiesībām un vārda brīvību.

28. ${ }^{1}$ pantam (Darba izmantošana parodiju vai karikatūru veidošanā) jābūt šādam:

(1) Bez autora piekrišanas un atlīdzības samaksas drīkst izmantot autordarbu parodiju vai karikatūru veidošanai.

(2) Veidojot parodiju vai karikatūru, izmantoto darbu drīkst pārveidot tikai tik, ciktāl tas nepieciešams, lai pievienotu humora vai izsmiekla izpausmi.

(3) Darba pārveidošana nedrīkst darbu izkropḷot, sagrozīt vai pārveidot tādā veidā, kas var kaitēt autora godam vai cien̦ai, kā arī nedrīkst būt pretrunā ar autora darba normālas izmantošanas noteikumiem un nepamatoti ierobežot autora likumīgās intereses.

(4) Veidojot parodiju vai karikatūru, nav obligāti jānorāda izmantotā darba nosaukums un autora vārds.

\section{Creating Parodies as a Restriction of Copyright}

\section{Abstract}

In certain cases, a literary or artistic work created by the author may be used without the author's permission, based on the copyright restrictions specified by law. The purpose of these restrictions is to strike a balance between the right of an author and rights of society. One of the restrictions is the right on creation of parodies and caricatures, which is an essential component of freedom of expression.

At the same time, the author has the right to take actions against the distortion of his work, because there is a very narrow line between parody and distortion. What seems like a funny joke to one person may seem offensive and resentful to another. If the author considers that his work is distorted, if it infringes the author's honour or dignity, then such action constitutes an infringement of the author's moral rights and is considered a violation.

In order to avoid the creation of inappropriate parodies or caricatures, it would be advisable to make amendments to the Copyright Law that would ensure a balance between the author's right to dignified use of his work and the society's right of freedom of expression and inadmissibility of censorship.

Keywords: copyright, freedom of expression, parody. 


\section{Avoti un literatūra}

\section{Tiesību akti}

1. Autortiesību likums: Latvijas Republikas likums. Latvijas Vēstnesis. 148/150(2059/2061), 27.04.2000.

2. Bernes konvencija par literatūras un mākslas darbu aizsardzību: starptautisks dokuments. Latvijas Vèstnesis. 29(2794), 21.02.2003.

3. Consolidation Copyright Act (R.S.C., 1985, c. C-42). Government of Canada. Iegūts no: https:// laws-lois.justice.gc.ca/eng/acts/c-42/

4. Eiropas Parlamenta un Padomes Direktīva (ES) 2019/790 (2019. gada 17. aprīlis) par autortiesībām un blakustiesībām digitālajā vienotajā tirgū un ar ko groza Direktīvas 96/9/EK un 2001/29/EK (Vienotā digitālā tirgus direktīva). Eiropas Savienības Oficiālais Vēstnesis. L130, 17.05.2019.

5. Eiropas Parlamenta un Padomes Direktīva 2001/29/EK (2001. gada 22. maijs) par dažu autortiesību un blakustiesību aspektu saskaṇošanu informācijas sabiedrībā (Informācijas sabiedrības direktīva). Eiropas Savienības Oficiālais Vēstnesis. L167, 22.06.2001.

6. Latvijas Republikas Satversme: Latvijas valsts likums: pieṇemta Satversmes sapulcē 1922. gada 15. februārī un stājās spēkā 1922. gada 7. novembrī. Latvijas Vēstnesis. 43, 01.07.1993.

7. Par Vispasaules intelektuālā īpašuma organizācijas (WIPO) līgumu par autortiesībām: Latvijas Republikas likums. Latvijas Vēstnesis. 53/54, 17.02.2000.

8. Republic of Lithuania: Law on Copyright and Related Rights: Law No. VIII-1185 of May 18, 1999. WIPO IP PORTAL. Iegūts no: https://wipolex.wipo.int/en/text/496613

9. United Kingdom: The Copyright, Designs and Patents Act 1988. WIPO IP PORTAL. Iegūts no: https:/wipolex.wipo.int/en/text/127366

10. Vispārējā cilvēktiesību deklarācija: ANO: starptautisks dokuments. Latvijas Republikas Augstākās Padomes un Valdības Ziṇotājs. 21, 24.05.1990.

\section{Tiesu prakse}

11. Eiropas Savienības Tiesas 2014. gada 3. septembra spriedums lietā Nr. C-201/13 Johan Deckmyn un Vrijheidsfonds VZW pret Helena Vandersteen $u$. c. Iegūts no: http://curia.europa.eu/juris/ document/document.jsf?text=\&docid=157281\&pageIndex=0\&doclang=LV\&mode=1st\&dir $=\&$ occ $=$ first $\&$ part $=1 \&$ cid $=6255183$

\section{Literatūra}

12. Blomqvist, J. 2014. Moral Rights, Primer on International Copyright and Related Rights. Cheltenham: Edward Elgar Publishing.

13. Blūmfelds, A. 2004. Noraida Rušenieka prasību pret Viesturu Dūli. Apollo.lv. 04.03.2004. Iegūts no: https://www.apollo.lv/4684477/noraida-rusenieka-prasibu-pret-viesturu-duli

14. Cohen, J. H. Restrictions on Copyright and their Abuse. European Intellectually Property Review. 10, 2005.

15. Curry, E. K. 2007. Business Law. New York: Kaplan Publishing.Fernández-Molina, J. C., Peis, E. 2001. The Moral Rights of Authors in the Age of Digital Information. Iegūts no: doi:10.1002/10974571(2000)9999:9999\%3C::AID-ASI1060\%3E3.0.CO;2-B

16. Gulbis, R., Tomsone, I. Autortiesību ierobežošana izglītības un zinātniskās pētniecības mērḳiem. Juridiskā Zinātne. 4, 2013, 26-39. Iegūts no: https:/www.journaloftheuniversityoflatvialaw.lu.lv/ fileadmin/user_upload/lu_portal/projekti/journaloftheuniversityoflatvialaw/No4/R_Gulbis.pdf 
Ingrīda Veikša. Parodiju veidošana kā autora tiesību ierobežojums

17. Letonika.lv [Terminu un svešvārdu skaidrojošā vārdnīca]. Iegūts no: https://www.letonika.lv/ default.aspx

18. Lewinski, S. 2008. International Copyright Law and Policy. Oxford University Press.

19. Research and Analysis: Parody and pastiche. Report 3: Copyright and the economic effects of parody. UK Intellectual Property Office. 15 March 2013. Iegūts no: https://www.gov.uk/government/publications/parody-and-pastiche

20. Satija, M. P., Martínez-Ávila, D. 2019. Plagiarism: An essay in terminology. DESIDOC Journal of Library E Information Technology. 39(2), 87-93. Iegūts no: doi: 10.14429/djlit.39.2.13937

21. Stewart, M. S. 1983. International Copyright and Neighbouring Rights. London: Butterworths.

22. Strong, W. S. 1999. The Copyright Book. A Practical Guide. 5th ed. Massachusets, London, England: The MIT Press Cambridge.

23. Vanzovičs, S. 2003. Cik sver gods un cieņa? Apollo.lv. 15.07.2003. Iegūts no: https://www.apollo. lv/4669774/cik-sver-gods-un-ciena

24. WIPO-Administered Treaties: Contracting Parties Berne Convention (Total Contracting Parties: 179). WIPO IP PORTAL. Iegūts no: https://wipolex.wipo.int/en/treaties/ShowResults?start_ year=ANY\&end_year $=$ ANY\&search_what $=C \&$ code $=$ ALL\&treaty_id=15 